\title{
Perancangan Aplikasi Pengacakan Pemenang Undian Berhadiah Menggunakan Metode Blum-Blum Shub Berbasis Android
}

\author{
Citono Harahap, Garuda Ginting, Taronisokhi Zebua \\ Prodi Teknik Informatika, STMIK Budi Darma, Medan, Indonesia \\ Email: citonoharahap58@gmail.com \\ Submitted 15-04-2020; Accepted 23-04-2020; Published 26-04-2020
}

\begin{abstract}
Abstrak
Undian berhadiah atau biasanya dikenal dengan lotere adalah salah satu cara untuk menghimpun dana yang dipergunakan untuk proyek kemanusiaan dan kegiatan sosial atau suatu cara untuk menentukan pemenang secara acak. Jadi, undian melakukan cara pemberian hadiah yang dilakukan secara acak dan undian bersinonim dengan lotere terdapat untung-untungan mengadu nasib. Perancangan sebuah aplikasi pengacakan pemenang undian berhadiah merupakan salah satu cara yang lebih modern dan dapat menarik banyak peserta undian berhadiah untuk mengikuti undian tersebut dengan mengurangi biaya untuk mencetak dan membagikan kupon undian. Salah satunya adalah metode blum blum shub yang merupakan suatu metode yang berfungsi men-generate bilangan acak secara proses matematis dengan output yang dihasilkan adalah deretan angka biner.Penelitian ini menguraikan penerapan metode blum blum shub dengan mengacak angka angka kupon undian yang telah disebarkan sebelumnya sehingga didapatkan angka yang dijadikan sebagai pemenang.Aplikasi yang dirancang hanya mensimulasikan proses penginputan angka angka undian serta proses pengacakannya hingga didapatkan angka pemenang.
\end{abstract}

Kata Kunci: Pengacakan, Blum Blum Shub, Undian.

\begin{abstract}
Lottery or commonly known as a lottery is one way to raise funds used for humanitarian projects and social activities or a way to determine the winner randomly. So, the lottery does a random gift-giving process and the lottery is synonymous with the lottery. The design of a lottery winner randomization application is one of the more modern ways and can attract many lottery participants to enter the lottery by reducing the cost of printing and distributing lottery tickets. One of them is the blum blub shub method, which is a method that functions to generate random numbers mathematically with the resulting output is a series of binary numbers. the numbers that are made as winners. The designed application only simulates the process of inputting lottery numbers and the randomization process to get the winning numbers.
\end{abstract}

Keywords: Randomization, Blum Blum Shub, Lottery.

\section{PENDAHULUAN}

Undian berhadiah atau biasanya dikenal dengan lotere adalah salah satu cara untuk menghimpun dana yang dipergunakan untuk proyek kemanusiaan dan kegiatan sosial atau suatu cara untuk menentukan pemenang secara acak. Jadi, undian melakukan cara pemberian hadiah yang dilakukan secara acak dan undian bersinonim dengan lotere terdapat unsure spekualitif (untung-untungan mengadu nasib).

Penentuan dalam penetapan sebuah undian adalah dengan memberikan petunjuk kepada peserta undian untuk membeli sepotong tiket yang diberi nomor. Nomor tiket-tiket ini kemudian secara acak dan nomor yang terpilih berhak atas hadiah tertentu. Pengadaan program undian berhadiah biasanya dilakukan secara manual salah satunya dengan menggunakan kupon berhadiah, kemudian diundi secara manual dengan mengambil satu persatu secara acak. Hal ini membuat penyelenggara undian mengeluarkan dana yang sangat besar dalam mencetak kupon undian[1].

Perancangan sebuah aplikasi pengacakan pemenang undian berhadiah merupakan salah satu cara yang lebih modern dan dapat menarik banyak peserta undian berhadiah untuk mengikuti undian tersebut dengan mengurangi biaya untuk mencetak dan membagikan kupon undian. Salah satunya adalah metode blum blum shub yang merupakan suatu metode yang berfungsi men-generate bilangan acak secara proses matematis dengan output yang dihasilkan adalah deretan angka biner.

Metode blum blum shub memiliki karakteristik khas yakni persamaan matematika yang melibatkan operator modulo dan juga fungsi perpangkatan di domain bilangan integer positif dan tak nol. Bagaimanapun juga generator ini mempunyai bukti keamanan yang kuat, dimana berhubungan dengan kualitas generator karena sulitnya faktorisasi integer[2].

Penelitian ini menguraikan penerapan metode blum blum shub dengan mengacak angka angka kupon undian sebanyak 100 peserta yang telah disebarkan sebelumnya dan mencari hanya satu orang pemenang saja sehingga didapatkan angka yang dijadikan sebagai pemenang.Aplikasi yang dibangun hanya mensimulasikan proses penginputan angka angka undian serta proses pengacakannya hingga didapatkan angka pemenang.

\section{METODE PENELITIAN}

\subsection{Perancangan}

Perancangan atau desain didefinisikan sebagai proses aplikasi berbagai teknik dan prinsip bagi tujuan pendefinisian suatu perangkat, suatu proses atau sistem dalam detail yang memadai untuk memungkinkan realisasi fisiknya[3]. Perancangan adalah untuk memen uhi kebutuhan kepada pemakai sistem dan untuk gambaran yang jelas kepada pemogram komputer dan ahli-ahli teknik lainnya yang telibat[4]. 
Berdasarkan pendapat di atas perancangan adalah suatu proses yang direncanakan dan disusun secara detail untuk memberikan gambaran yang jelas kepada para perancang yang terlibat untuk membangun suatu aplikasi atau perangkat agar dapat memenuhi kebutuhan pemakai sistem dan sesuai dengan tujuan.

\subsection{Aplikasi}

Aplikasi adalah pemecahan masalah yang menggunakan salah satu teknik pemrosesan data yang biasanya berpacu pada sebuah komputansi yang diinginkan atau diharapkan[5]. Aplikasi adalah program siap pakai yang dapat digunakan untuk perintah-perintah dari pengguna dengan tujuan mendapatkan hasil yang lebih akurat sesuai dengan tujuan pembuatan[6].

Berdasarkan pendapat di atas aplikasi dapat diartikan sebagai penerapan dari rancangan sistem untuk mengolah data yang menggunakan aturan atau ketentuan tertentu dari bahasa pemrograman yang digunakan. Aplikasi juga dapat diartikan suatu program komputer yang dibuat untuk mengerjakan dan melaksanakan tugas khusus dari pengguna. Aplikasi merupakan suatu subkelas perangkat lunak komputer yang memanfaatkan kemampuan komputer langsung untuk melakukan suatu tugas yang diinginkan pengguna.

\subsection{Pengacakan}

Pengacakan adalah pengumpulan subjek ke dalam kelompok-kelompok eksperimen dan kontrol agar menjadi lebih objektif[7]. Tujuan pengacakan adalah mengurangi bias yang disebabkan oleh kesalahan sistematis. Berdasarkan tujuan tersebut, maka pengacakan dapat diartikan sebagai hal yang mendasari setiap satuan percobaan yang memiliki peluang yang sama agar mengurangi kesalahan sistematis.

Randomisasi atau pengacakan tidak selalu menjamin bisa menghasilkan sampel yang benar- benar objektif. Jadi, randomisasi dapat mengubah kesalahan sistematis menjadi kesalahan acak yang dapat diterima. Beberapa cara untuk melakukan proses pengacakan diantaranya[7]adalah:

1. Menggunakan tabel bilangan random.

2. Penarikan undian.Penggunaan bilangan random di komputer.

\subsection{Undian Berhadiah}

Lotere atau undian berhadiah adalah satu cara untuk menghimpun dana yang dipergunakan untuk proyek kemanusiaan dan kegiatan sosial[8]. Undian sendiri dapat diartikan sebagai suatu cara untuk menentukan pemenang secara acak. Jadi, undian adalah cara pemberian hadiah yang dilakukan secara acak. Berdasarkan pengertian tersebut kata undian bersinonim dengan lotere, dimana lotere terdapat unsure spekulatif (untung-untungan mengadu nasib). Kata undian pada masyarakat pengertiannya dibedakan, sehingga hukumnya pun berbeda, kalau dalam undian tidak terdapat pihak yang merasa dirugikan, sedangkan dalam lotere terdapat pihak yang dirugikan.

\subsection{Blum-blum shub (BBS)}

Blum-blum shub (BBS) merupakan suatu pseudo random number generator yang diajukan pada tahun 1986 oleh Lenore Blum, Manue Blum dan Michael Shub, BBS memiliki bentuk persamaan Sebagai berikut[13]

$$
\mathrm{X}+1=\mathrm{X}^{2} \bmod ^{\mathrm{n}}
$$

dimana m merupakan hasil dari perkalian dua buah bilangan prima besar $\mathrm{p}$ dan q serta output- nya dalam leasr significant bit dari $\mathrm{X}_{\mathrm{n}}$ dimana hal yang sama sebagai parity dari $\mathrm{X}_{\mathrm{n}}$. Dua buah bilangan prima $\mathrm{p}$ dan $\mathrm{q}$ harus kongruen terhadap 3 mod 4 dan Greatest Common Divisor (GCD) harus kecil. Generator ini sering digunakan untuk aplikasi kriptografi karena generator ini tidak begitu cepat. Generator ini mempunyai bukti keamanan yang kuat, dimana berhubungan dengan kualitas generator karena sulitnya faktorisasi integer. Berikut langkah langkah metode BBS[13], yaitu:

1. Pilih dua bilangan prima $\mathrm{p}$ dan $\mathrm{q}$, dimana $\mathrm{p}$ dan $\mathrm{q}$ keduanya kongruen terhadap 3 modulo $4 . \mathrm{P}=3 \bmod 4$ dan $\mathrm{q}=3$ $\bmod 4$.

2. Hasilkan bilangan bulat blum $\mathrm{n}$ dengan menghitung $\mathrm{n}=\mathrm{p} \times \mathrm{q}$.

3. Pilih lagi sebuah bilangan acak s sebagai umpan, bilangan yang dipilih harus memenuhi kriteria:

a. $2 \leq \mathrm{s}<\mathrm{n}$.

b. $\mathrm{S}$ dan $\mathrm{n}$ adalah relatif prima.

4. Hitung nilai $\mathrm{x} 0=\mathrm{s}^{2} \bmod \mathrm{n}$.

5. Hasilkan bilangan bit acak dengan cara. $\mathrm{x} 1=\mathrm{x}^{2} \bmod \mathrm{n}$

Hasilkan $\mathrm{zi}=$ bit-bit yang diambil dari $\mathrm{x} 1$. Bit yang diambil bisa merupakan LSB atau hanya satu bit atau sebanyak $\mathrm{j}$ bit (j tidak melebihi $\log 2(\log 2 \mathrm{~b})$. Bilangan bit acak dapat digunakan langsung atau di format dengan aturan tertentu hingga menjadi bilangan bulat.

\section{HASIL DAN PEMBAHASAN}

Tahap analisa merupakan tahap yang sangat berpengaruh dan menentukan terhadap tahap selanjutnya. Analisa terhadap sistem merupakan tahap yang sangat penting untuk mengetahui proses yang terjadi di dalam aplikasi yang akan dirancang, dalam hal ini menggunakan algoritma blum blum shub pada aplikasi pengacakan pemenang undian berhadiah. 
Algoritma blum blum shub merupakan sebuah algoritma pembangkit bilangan acak yang termasuk di dalam kategori cryptographically secure pseudo random number generator. Pengundian berhadiah merupakan salah satu cara yang dilakukan sebuah perusahaan penjualan untuk meningkatkan penjualannya. Biasanya untuk mendapatkan pemenang, langkah yang dilakukan adalah dengan memasukkan kertas yang memiliki nomor undian ke dalam sebuah box atau kotak, kemudian dikocok dan diambil sebuah kertas yang memiliki nomor undian pemenangnya. Proses penentuan pemenang yang akan dilakukan di dalam aplikasi adalah dengan menyebar nomor undian secara digital ke para peserta undian, kemudian nomornomor tersebut di-input-kan ke dalam database dan akan diacak di dalam aplikasi berdasarkan algoritma blum- blum shub untuk mendapatkan nomor pemenangnya.

\subsection{Penerapan Algoritma Blum Blum Shub}

Proses pengacakan dalam penentuan pemenang undian berhadiah pada algoritma blum blum shub dilakukan secara bertahap. Langkah- langkah dalam penentuan pemenang menggunakan algoritma blum-blum shub dapat dilihat dari contoh sebagai berikut:

Peserta dalam undian pemenang yang berjumlah 100 peserta dengan nomor undian yang telah ditetapkan dengan urutan nomor undian 100 sampai dengan 199 nomor undian. Berhubungan dengan nomor peserta yang telah dibagikan secara digital dapat dilihat dari tabel sebagai berikut:

Proses pengacakan dalam penentuan pemenang undian berhadiah pada algoritma blum blum shub dilakukan secara bertahap. Langkah-langkah dalam penentuan pemenang menggunakan algoritma blum-blum shub dapat dilihat dari contoh sebagai berikut:

Peserta dalam undian pemenang yang berjumlah 100 peserta dengan nomor undian yang telah ditetapkan dengan urutan nomor undian 100 sampai dengan 199 nomor undian. Berhubungan dengan nomor peserta yang telah dibagikan secara digital dapat dilihat dari tabel sebagai berikut:

Tabel 1. Tabel Peserta Undian

\begin{tabular}{|c|c|c|c|c|c|c|c|c|}
\hline No & No. Undian & Nama Peserta & No & No. Undian & Nama Peserta & No & No. Undian & Nama Peserta \\
\hline 1 & 100 & Udin & 36 & 135 & Karina & 71 & 170 & Gord \\
\hline 2 & 101 & Messi & 37 & 136 & Selena & 72 & 171 & Hayabusa \\
\hline 3 & 102 & Ibrahimovic & 38 & 137 & Kaja & 73 & 172 & Lolita \\
\hline 4 & 103 & Ronaldo & 39 & 138 & Change & 74 & 173 & Fanny \\
\hline 5 & 104 & Owen & 40 & 139 & Hanabi & 75 & 174 & Rafaela \\
\hline 6 & 105 & Beckham & 41 & 140 & Uranus & 76 & 175 & Bane \\
\hline 7 & 106 & Bambang & 42 & 141 & Martis & 77 & 176 & Franco \\
\hline 8 & 107 & Firza & 43 & 142 & Valir & 78 & 177 & Akai \\
\hline 9 & 108 & Andhika & 44 & 143 & Lesley & 79 & 178 & Alucard \\
\hline 10 & 109 & Lutfi & 45 & 144 & Gusion & 80 & 179 & Alice \\
\hline 11 & 110 & Siska & 46 & 145 & Angela & 81 & 180 & Claude \\
\hline 12 & 111 & Fitri & 47 & 146 & Jawhead & 82 & 181 & Kante \\
\hline 13 & 112 & Fitra & 48 & 147 & Pharsa & 83 & 182 & Makalele \\
\hline 14 & 113 & Risky & 49 & 148 & Zhask & 84 & 183 & Lampard \\
\hline 15 & 114 & Riska & 50 & 149 & Hylos & 85 & 184 & Joe Cole \\
\hline 16 & 115 & Rocky & 51 & 150 & Digger & 86 & 185 & Vita \\
\hline 17 & 116 & Aldous & 52 & 151 & Lancelot & 87 & 186 & Anggi \\
\hline 18 & 117 & Freya & 53 & 152 & Odette & 88 & 187 & Rudi \\
\hline 19 & 118 & Minotaur & 54 & 153 & Argus & 89 & 188 & Bowo \\
\hline 20 & 119 & Layla & 55 & 154 & Grock & 90 & 189 & Yayah \\
\hline 21 & 120 & Zilong & 56 & 155 & Irithel & 91 & 190 & Fathan \\
\hline 22 & 121 & Eudora & 57 & 156 & Karrie & 92 & 191 & Opi \\
\hline 23 & 122 & Clint & 58 & 157 & Roger & 93 & 192 & Roihan \\
\hline 24 & 123 & Tigreal & 59 & 158 & Vexana & 94 & 193 & Budi \\
\hline 25 & 124 & Nana & 60 & 159 & Aurora & 95 & 194 & Steven \\
\hline 26 & 125 & Saber & 61 & 160 & Hilda & 96 & 195 & William \\
\hline 27 & 126 & Balmond & 62 & 161 & Jhonson & 97 & 196 & Widya \\
\hline 28 & 127 & Miya & 63 & 162 & Moskov & 98 & 197 & Suci \\
\hline 29 & 128 & Cyclops & 64 & 163 & Yi Shun Shin & 99 & 198 & Rida \\
\hline 30 & 129 & Helcurt & 65 & 164 & Ruby & 100 & 199 & Roy \\
\hline 31 & 130 & Harley & 66 & 165 & Alpha & & & \\
\hline 32 & 131 & Gatotkaca & 67 & 166 & Sun & & & \\
\hline 33 & 132 & Lapu-lapu & 68 & 167 & Chou & & & \\
\hline 34 & 133 & Estes & 69 & 168 & Kagura & & & \\
\hline 35 & 134 & Bruno & 70 & 169 & Natalia & & & \\
\hline
\end{tabular}


Langkah-langkah dalam penentuan pemenang undian berhadiah berdasarkan algoritma blum blum shub adalah sebagai berikut:

1. Pilih dua buah bilangan prima rahasia $\mathrm{p}$ dan $\mathrm{q}$, masing-masing kongruen terhadap 3 modulo $4 . \mathrm{p}=3$ mod 4 dan $\mathrm{q}=3$ mod 4. Dimana nilai bilangan prima yang diambil $\mathrm{p}=251, \mathrm{q}=307$ sudah masing-masing kongruen terhadap 3 modulo 4. $\mathrm{p}=251 \bmod 4=3, \mathrm{q}=307 \bmod 4=3$

2. Hasilkan bilangan bulat $\mathrm{n}$ dengan menghitung $\mathrm{n}=\mathrm{p} \times \mathrm{q}$

$$
\begin{aligned}
\mathrm{n} & =\mathrm{p} \times \mathrm{q} \\
& =251 \times 307 \\
& =77057
\end{aligned}
$$

3. Pilih lagi bilangan acak s sebagai umpan, bilangan yang dipilih harus memenuhi criteria maka bilangan acak s yang diambil 52116 sebagai umpan.
a. $2 \leq \mathrm{s}<\mathrm{n}$
b. $\mathrm{s}$ dan $\mathrm{n}$ adalah relatif prima
$\mathrm{s}=52116$

4. Hitung nilai $x_{0}=s^{2} \bmod n$

Setelah mendapatkan hasil dari nilai $\mathrm{x}$; atau sebut dengan angka desimal dari nilai $\mathrm{x}$ maka langkah yang dilakukan dirubah ke bilangan biner.

$$
\begin{aligned}
\mathrm{x}_{0} & =52116^{2} \bmod 77057 \\
& =2716077456 \bmod 77057 \\
& =49377=1100000011100001
\end{aligned}
$$

5. Hasilkan bilangan bit acak dengan cara hitung $\mathrm{x}_{1}=\mathrm{x}_{0}^{2} \bmod \mathrm{n}$ sebagai berikut:

$$
\begin{aligned}
\mathrm{x}_{1} & =49377^{2} \bmod 77057 \\
& =2438088129 \bmod 77057 \\
& =4649=1001000101001
\end{aligned}
$$

6. Bahwa bit - bit akhir yang diambil yang dimaksud adalah (least significant bit) angka terakhir dari setiap nilai x; dan dari tiap iterasi untuk mendapatkan nomor pemenang, karena nomor peserta memiliki 3 digit angka, maka iterasi dilakukan sebanyak n kali hingga hasil desimal dari keseluruhan LSB yang diambil terdiri dari 3 digit dan LSB yang digunakan 1 bit.

$$
\begin{aligned}
\mathrm{x}_{0} & =49377 \\
& =1100000011100001 \\
& =\mathrm{LSB}=1 \\
\mathrm{x}_{1} & =4649 \\
& =1001000101001 \\
& =\mathrm{LSB}=1 \\
\mathrm{x}_{2} & =4649^{2} \bmod 77057 \\
& =21613201 \bmod 77057 \\
& =37241 \\
& =1001000101111001 \\
& =\mathrm{LSB}=1 \\
\mathrm{x}_{3} & =372412 \bmod 77057 \\
& =1386892981 \bmod 77057 \\
& =20195 \\
& =100111011100011 \\
& =\mathrm{LSB}=1 \\
\mathrm{x}_{4} & =20195^{2} \bmod 77057 \\
& =407838025 \bmod 77057 \\
& =52381 \\
& =1100110010011101 \\
& =\mathrm{LSB}=1 \\
\mathrm{X}_{5} & =52381^{2} \bmod 77057 \\
& =2743769161 \bmod 77057 \\
& =562 \\
& =1000110010 \\
& =\mathrm{LSB}=0 \\
\mathrm{X}_{6} & =562^{2} \bmod 77057 \\
& =315844 \bmod 77057 \\
& =7616 \\
& =1110111000000 \\
& =\mathrm{LSB}=0 \\
&
\end{aligned}
$$


Nilai LSB dari $\mathrm{X}_{0}$ sampai $\mathrm{X}_{6}$ adalah karena jumlah digit desimal biner hasil $\mathrm{X}_{0}-\mathrm{X}_{6}$ berjumlah 3 digit maka proses berhenti. Least Significant Bit dari $\mathrm{X}_{0}$ sampai $\mathrm{X}_{6}$ adalah 1111100, dikonversi ke dalam bilangan desimal 124. Jadi pemenang undian berhadiah yang didapatkan adalah dengan nomor undian 124 dengan nama Nana.

\subsection{Implementasi}

Pengujian aplikasi dilakukan untuk mengetahui apakah aplikasi sudah berjalan dengan baik dan benar. Pengujian aplikasi dilakukan dengan menggunakan emulator android yang terdapat di dalam aplikasi eclipse juno, adapun hasil pengujian aplikasi adalah sebagai berikut:

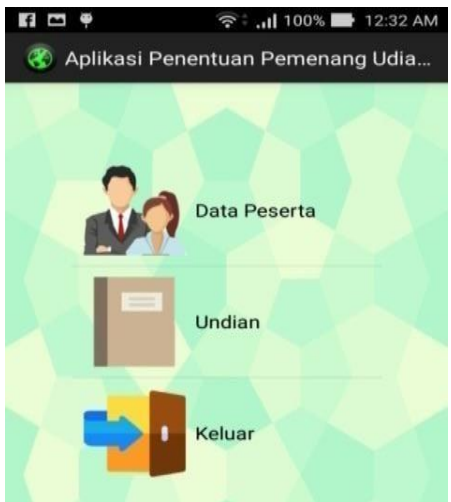

Gambar 1. Tampilan Pengujian Halaman Utama

Berdasarkan gambar 1. pengujian halaman utama dapat berjalan dengan baik dan tombol-tombol yang terdapat pada halaman ini sudah berfungsi dengan baik.

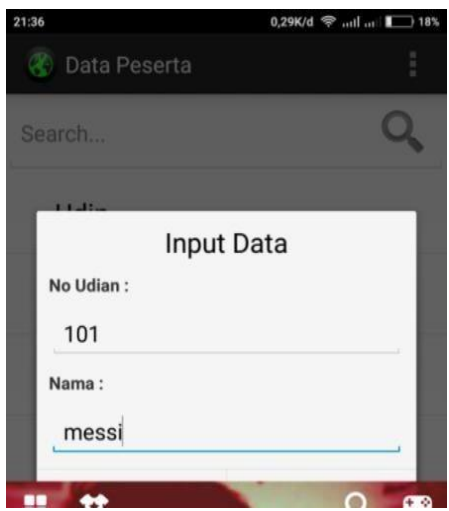

Gambar 2. Hasil Pengujian Form Input Data Peserta

Berdasarkan gambar 2. dilakukan peng- input-an ke dalam database dengan meng-input nomor undian 101 dengan nama Messi. Untuk melakukan penyimpanan data peserta ditekan tombol simpan, untuk membatalkan digunakan tombol batal dan untuk kembali ke halaman utama digunakan tombol back hp.

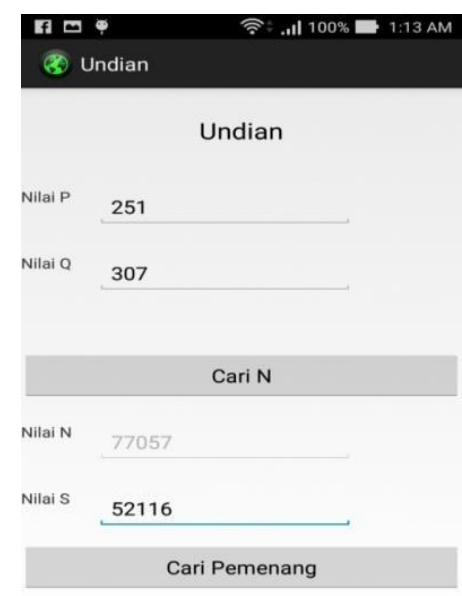

Gambar 3. Pengujian Form Undi 
Berdasarkan gambar 3. pengujian dilakukan dengan melakukan peng-input-an pada nilai p dan q, kemudian menekan tombol cari nilai $\mathrm{n}$ untuk mendapatkan nilai $\mathrm{n}$ dan kembali melakukan peng-input-an terhadap nilai s dan menggunakan tombol cari pemenang untuk mendapatkan pemenang.

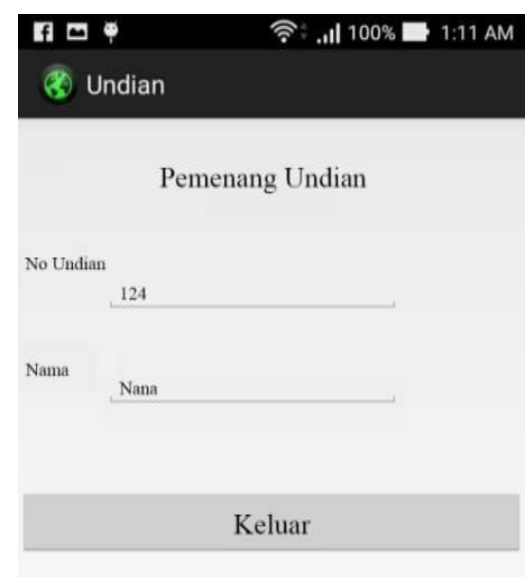

Gambar 4. Pengujian Form Hasil

Berdasarkan gambar 4. form hasil akan menampilkan nomor undian dan nama pemenang undian yang didapatkan dari perhitungan form sebelumnya yaitu pada form undian.

\section{KESIMPULAN}

Berdasarkan pembahasan dan evaluasi dari bab-bab sebelumnya, maka dapat diambil kesimpulan-kesimpulan. Adapun kesimpulan- kesimpulan tersebut adalah sebagai berikut:

1. Proses penentuan pemenang undian dapat dilakukan dengan mengumpulkan nomor- nomor undian yang telah dibagikan ke dalam suatu database untuk memudahkan dalam melakukan pengundian.

2. Blum blum shub merupakan sebuah pseudo random generator, dalam penentuan pemenang undian berhadiah, algoritma melakukan perhitungan terhadap bilangan prima yang kongruen terdapat 3 modulo 4, kemudian mengambil nilai-nilai least significant bit pada tiap iterasi yang terjadi.

3. Perancangan aplikasi penentuan pemenang undian berhadiah dapat dilakukan dengan menggunakan Unified Modelling Language sebagai alat bantu perancangannya dan Eclipse Juno sebagai tools untuk membangun aplikasi yang berbasis Android..

\section{REFERENCES}

[1] R. Aurelius and N. Diaz, "Penerapan c4.5 dalam prediksi penipuan pemenang undian berhadiah menggunakan rapid miner," Semin. Nas. Inform. 2015 207, pp. 207-210, 2015.

[2] M. B. Sanjaya, "Perancangan dan Implementasi Random Number Blum Blum Shub pada Dynamic Cell Spreading untuk Pengamanan Berkas," no. November 2017, pp. 167-173.

[3] N. Dengen and H. R. Hatta, "Perancangan Sistem Informasi Terpadu Pemerintah Daerah Kabupaten Paser," J. Inform. Mulawarman, vol. 4, no. 1, pp. 47-54, 2009.

[4] I. Jurnal, C. Science, and F. T. I. Unsa, “ANALISIS DAN PERANCANGAN SISTEM INFORMASI STOK OBAT PADA APOTEK ARJOWINANGUN Hanik Mujiati, Sukadi," vol. 9330, pp. 1-6, 1999.

[5] A. Juansyah, "PEMBANGUNAN APLIKASI CHILD TRACKER BERBASIS ASSISTED - GLOBAL POSITIONING SYSTEM ( A-GPS ) DENGAN PLATFORM ANDROID Jurnal Ilmiah Komputer dan Informatika ( KOMPUTA ),” J. Ilm. Komput. dan Inform., vol. 1, no. 1, pp. 1-8, 2015.

[6] H. Abdurahman and A. R. Riswaya, “Aplikasi Pinjaman Pembayaran Secara Kredit Pada Bank Yudha Bhakti,” J. Comput. Bisnis, vol. 8, no. 2, pp. 61-69, 2014.

[7] et. a. D.P.Andriani, N.W.Setyanto, Desain dan Analisis Eksperimen, UB Press. Malang, 2017.

[8] T. Ilmiah and M. M. Batubara, "PERANCANGAN SISTEM APLIKASI UNDIAN BERHADIAH PADA PT . PS MAJU BERSAMA MENGGUNAKAN LINEAR CONGRUENT METHOD ( LCM ),” no. September, pp. 73-81, 2014.

[9] J.Umtoro, Genius Matematika, Wahyumedia. Bandung, 2017.

[10] K.Y.Tung, Memahami Teori Bilangan dengan Mudah dan Menarik, PT.Grasind. Jakarta, 2008.

[11] A. Handayanto, "Peranan sistem modulo dalam penentuan hari dan pasaran," pp. 1-10,2014

[12] E. R. Djuwitaningrum and M. Apriyani, "Teknik Steganografi Pesan Teks Menggunakan Metode Least Significant Bit dan Algoritma Linear Congruential Generator ( Text Message Steganography Using Least Significant Bit Method and Linear Congruential Generator Algorithm )," vol. IV, no. November, pp. 79-85, 2016.

[13] M. B. Sanjaya and P. A. Telnoni, "Implementasi Random Number Blum-Blum-Shub Dan Chaotic Function Untuk Modifikasi Key Generating Pada Kriptografi Aes Implementasi Blum-Blum-Shub Dan Chaotic Function Untuk Modifikasi Key Generating Pada Aes Implementation of Blum-Blum-Shub and Chaotic Func,” J. Elektro Telekomun. Terap. Desember, pp. 154-165, 2015.

[14] N.Safaat, PEMROGRAMAN APLIKASI MOBILE SMARTPHONE DAN TABLET PC BERBASIS ANDROID. Bandung.

[15] A.Nugroho, Rekayasa Perangkat Lunak Berorientasi Objek dengan Metode USDP. Yogyakarta. 
JURIKOM (Jurnal Riset Komputer), Vol. 7 No. 2, April 2020 e-ISSN 2715-7393 (Media Online), p-ISSN 2407-389X (Media Cetak) DOI 10.30865/jurikom.v7i2.2112 Hal 301-307

[16] P. Sulistyorini, "Pemodelan Visual dengan Menggunakan UML dan Rational Rose,” J. Teknol. Inf. Din. Vol., vol. XIV, no. 1, pp. 23-29, 2009.

[17] G. G. W.Gata, Sukses Membangun Aplikasi Penjualan Dengan Java, PT.Elex Me. Jakarta, 2013. 